\title{
特集頭蓋底静眽の基礎と臨床（2）：錐体斜台部
}

\author{
頭蓋底静脈の読影 \\ —Venous Cross Road の重要性を中心に一
}

久 保 道 也 堀 江 幸 男 林 央 周*
桑 山 直 也*

\section{Clinical Aspects of the Venous System in Cerebral Angiography, especially for treating Vascular Lesions and Tumors at the Skull Base}

by

Michiya Kubo, M.D., Yukio Horie, M.D., Nakamasa Hayashi, M.D. ${ }^{*}$, Naoya Kuwayama, M.D. ${ }^{*}$, and Shunro Endo, M.D.*

from

Department of Neurosurgery, Stroke Center, Saiseikai Toyama Hospital

* Department of Neurosurgery, Faculty of Medicine, University of Toyama

Recently, Magnetic Resonance Angiography and three-dimensional CT angiography have become important tools for neurosurgeons and neuroradiologists. In the daily clinical diagnosis, the number of diagnostic cerebral angiographies performed has actually been reduced, but its dominant position in the evaluation of detailed information for advanced treatment of skull base diseases, such as dural arteriovenous fistulas, arteriovenous malformations, or skull base tumors, still remains and is much required.

Classical venous anatomy and landmarks are not described in this chapter. We illustrate how to obtain much clearer venous images and analyze venous hemodynamic conditions from the aspect of endovascular treatment or direct surgery. Practically important points of venous findings for treatments are also described here mainly from the standpoint of "venous cross roads".

(Received July 22, 2008; accepted August 1, 2008)

Key words : venous cross road, cerebral angiography, venous anatomy, skull base, endovascular treatment

Jpn J Neurosurg（Tokyo）17: 745-753, 2008

\section{はじめに}

本稿では，頭蓋底病変に関連した細かい脳静脈の 1 本 1 本の同定作業ではなく, 臨床の場で実際に症例を目の 前にした場合に，いかにしてポイントを押さえた頭蓋底 の脳静脈読影を行って実際の診断・治療に役立てるかに ついて述べたいと思う。
そのためには，以下の 2 点が重要と考えられる。一つ めは，脳血管撮影において局所の脳静脈に関する必要な 情報を得ようとする場合には，その静脈を意識した最適 の撮像条件を設定して撮影を行うべきであるという点で ある。そうした努力によって, 初めて必要とする情報が 十分に盛り込まれた静脈像を描出することができるとい える。 そして，もう一つは，「静脈の視点で考える」習慣

富山県済生会富山病院脳卒中センター脳神経外科 / T931-8533 富山市楠木 33-1〔連絡先：久保道也〕

Address reprint requests to : Michiya Kubo, M.D., Department of Neurosurgery, Stroke Center, Saiseikai Toyama Hospital, 33-1 Kusunoki, Toyama-shi, Toyama 931-8533, Japan

*富山大学医学部脳神経外科 


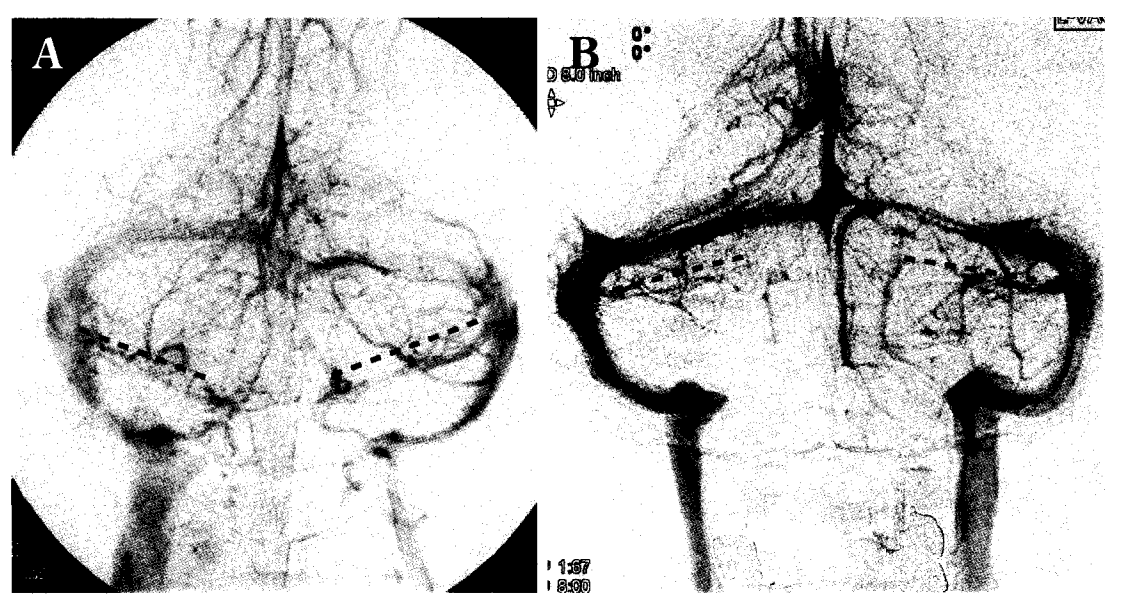

Fig. 1 Anteroposterior views under 30 degrees of cranial-angle $(\mathbf{A})$ and 10 degrees of caudal-angle (B) of the venous phase of vertebral angiograms. Dotted-lines demontrate the running courses of the superior petrosal sinuses.
を身に付け, venous cross road を十分に理解したうえで, ポイントを押さえた静脈読影を行うことである。

\section{脳血管撮影における 静哌画像の描出のための条件設定}

高性能の CT 装置の開発に伴い, きわめて解像度の優 れた 3 次元 CTA 画像の作製が, 脳静脈においても可能 になった。しかし，そこに示されているものはあくまで も形態のみであって, 流れ（flow）の要素はまったく示 されていない，そのため，flowの向き（どちらの方向に 向かって流れているか：順行性または逆行性）・速さ・ 停滞の有無などの情報を得ることはできない.

その一方で, 脳血管撮影においては, flow の情報が盛 り込まれている点で, 3 次元 CTA 画像よりも情報は多 い. しかし，flow の要素があるがゆえに読影が困難にな る場合があることも認識せねばならない，その代表的な ものが, 非造影血管系から還流した flow の合流により wash-out されて血管像が不明瞭になったり, 層流 (laminar flow）を形成したり, flow が拮抗したりするなどの点 である。この傾向は, 流速の遅い静脈相において, ょり 顕著になると考えられる。

こうした脳血管撮影に関する特性を十分認識すること は必要条件であり, それに静脈を描出するために最も適 した撮像条件設定を加えることによって, 初めて局所脳 静脈（特に深部や後頭蓋窩の静脈）の実践的読影を行う ための準備が整ったといえる.

\section{1 撮影角度設定のポイント}

通常の脳血管撮影は, 動脈の描出を意識して設定を行 う. 例えば, 椎骨動脈撮影の正面像において cranial angle を 30 度前後に設定すると, 後大脳動脈を可及的に長く
とらえて詳細な所見を得ることができるが, 椎骨動脈や 脳底動脈を長くとらえようとする場合にはこの角度は適 さない.したがって, 椎骨動脈や脳底動脈を長くとらえ るには, 垂直かむしろ caudal angle を軽くとつたほうが 詳細な情報を得ることができる.

治療に必要な静脈の情報を得るためには, その局所静 脈の描出に適した角度の設定が必要である。このことは 動脈相の描出には当たり前のように行われているが, 静 脈においても同様に意識する必要があると思われる。深 部静脈や後頭蓋窩静脈の読影を行う際に, 通常はキーと なる venous cross road を見つけ，そこから読影を始め る.

錐体静脈（petrosal vein；PV）は, 最も重要な venous cross road の一つである. 椎骨動脈撮影正面像の静脈相 においては, 上錐体静脈洞 (superior petrosal sinus；SPS) から PV を同定して, 読影を進めていくのが通常である. Fig. 1 に示したのは, 椎骨動脈撮影正面像の静脈相であ るが, cranial angleをかけて撮影した静脈相と caudal angleをかけて撮影した静脈相とでは, SPS の角度そのも のが大きく異なり，局所静脈の見え方も大きく違ってく ることはいうまでもない. また, 同じ画像で, basal vein of Rosenthal (BVR) の所見を得ようとする場合には, cranial angle をとると「逆ハート型」を呈した BVR の走行 や左右の吻合がきわめてわかりやすいが, caudal angle を とると BVR は横静脈洞と重なってしまって, 詳細な判 読が困難となる場合がある。また, その一方で, 頸静脈 球（jugular bulb；JB）近傍の情報を得るためには caudal angle をかけて撮影した静脈相のほうがより判読に適し ており，下錐体静脈洞（inferior petrosal sinus；IPS）の 走行や吻合部位などを確認しやすい.

次に, 側面像静脈相（特に後頭蓋窩）においては, 左 右の静脈や静脈洞が画像上で重複してしまうことが多い 

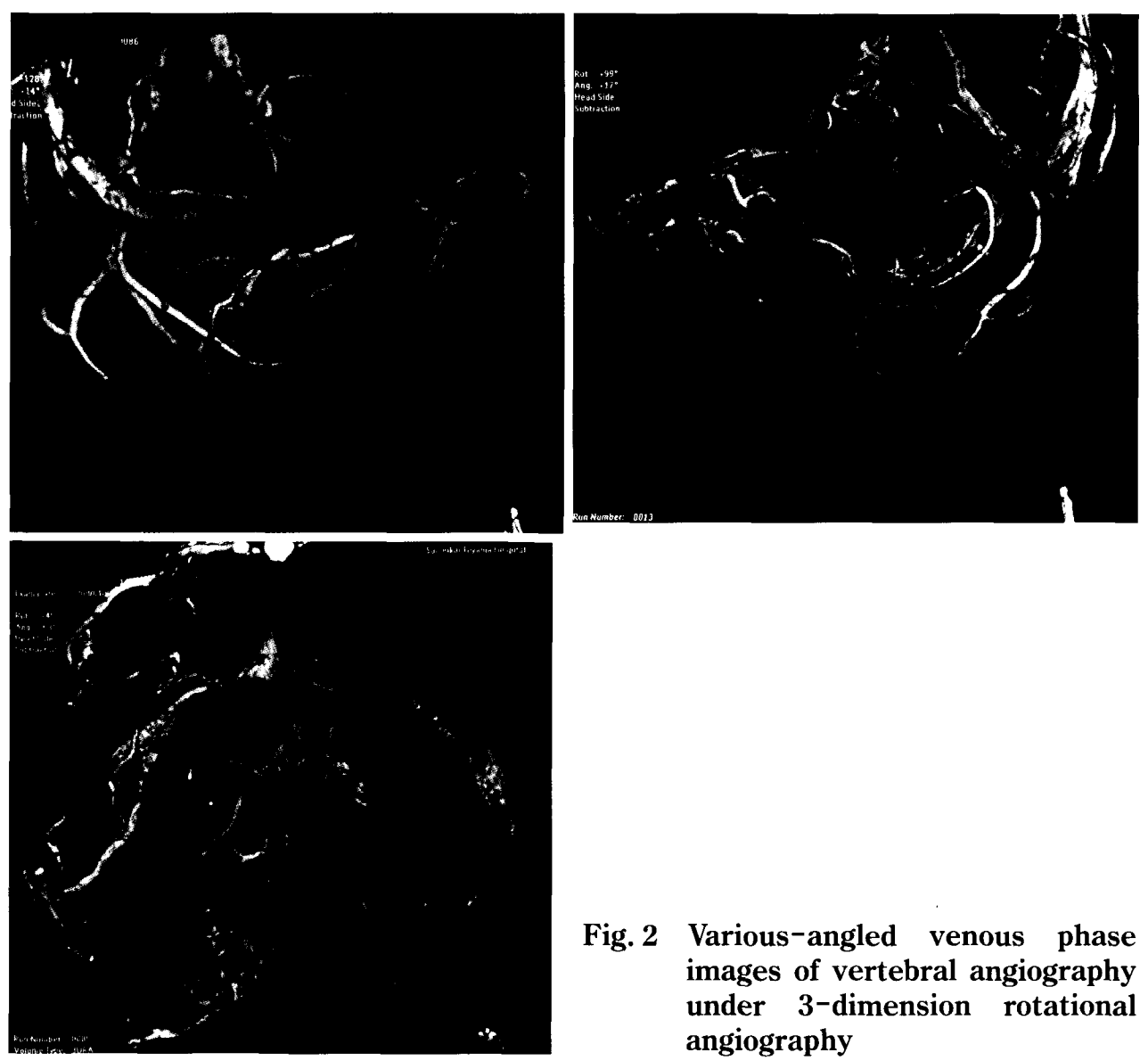

Fig. 2 Various-angled venous phase images of vertebral angiography under 3-dimension rotational angiography

ため, 左右の所見を誤って認識してしまうことがある. もちろん, 3 次元回転血管撮影 (3D-rotational angiography；3D-RA）を行うことができれば，このことはまっ たく問題にならない. 3D-RA においても, 動脈の 3D 画 像を作製する場合と静脈の $3 \mathrm{D}$ 画像を作製する場合で は, 造影剂の注入レート (時間当たりの注入量) や delay (造影剂注入から撮像開始までのインターバル)が異なつ ており，注意が必要である（Fig. 2)，3D-RA が不可能な 場合は，通常の側面像の撮影後に，側面からやや caudal angleをかけたり (近位側が画像上持ち上がる), cranial angle（遠位側が画像上持ち上がる）をかけたりして画像 上の分離を行ったうえで, 複数の撮影シリーズを比較し て読影を行うことによって左右を見分けることが可能で ある。

\section{2 総合読影の重要性}

描出される静脈相所見は, 動脈の吻合や flow のパ夕ー ンによって大きな影響を受けていることを十分に認識せ ねばならない。特に, 頸動脈撮影静脈相においては, 動 脈相における後交通動脈の発達の確認が必要であり, そ れによって視床からの静脈還流の描出が大きく異なって
くる，また，椎骨動脈撮影静脈相では，動脈相における 後大脳動脈の flow パターンが層流形成 (laminar flow) によって一側のみが強く描出されることがあるため，そ れを認識したうえでの読影が重要である。最終的には, それら複数の撮影シリーズの静脈相所見から総合読影を 行うことが必要と考えられる。

また, フィルムにプリントした画像のみでなく, 撮影 時と同様に画面上で動画として読影することも重要であ り, flow が拮抗した場合に生じる “to and fro” pattern な どの確認には必須である。

\section{「静脈の視点で考える」習慣と venous cross road を理解したうえでの ポイントを押さえた静眽読影}

\section{1]「静脈の視点で考える」}

BVR ならびにその分枝は解剖学的にきわめて興味深 い静脈であり, MRI が存在しない時代には, 脳のさまざ まな局所部位の解剖学的指標として用いられた.しかし, MRI が発達した現代においては,「機能的静脈解剖」と してとらえることのほうがより重要と思われる。 


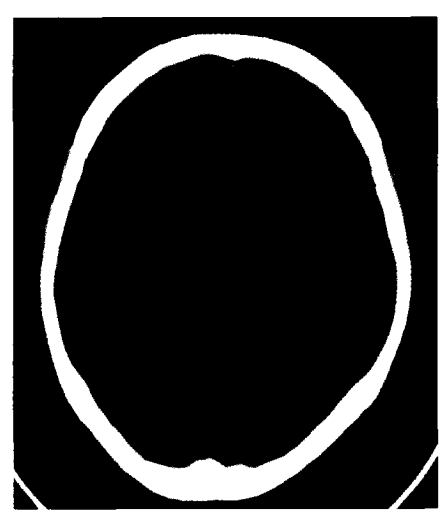

First day

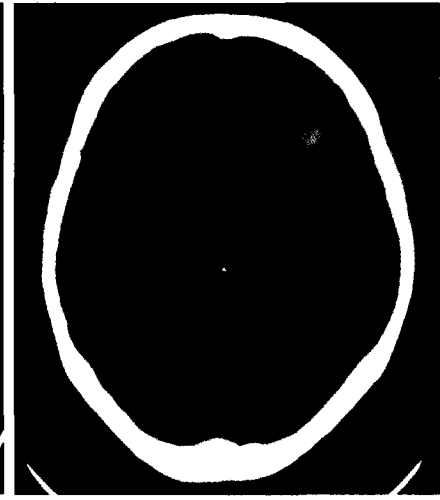

5 days later

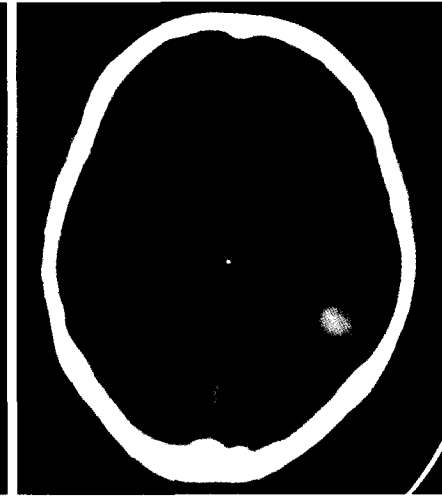

3 months later

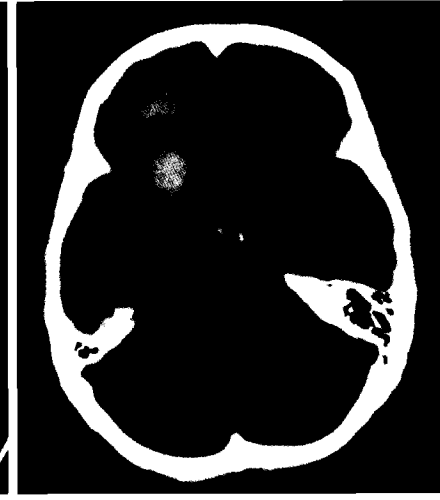

5 months later

Fig. 3 Case 1: CT scan shows that repeated intracerebral hemorrhages occurred 4 times at 3 different portions within 5 months.

Fig. 3 は，(左）前頭葉，(左）側頭葉，(右）前頭葉下 面と「時間的」にも「空間的」にも多発性の皮質下出血 を繰り返して発症し，当院に紹介された症例である。こ の症例に対して, 動脈の視点のみで考えると,「対唄病変 もあるので，アミロイド・アンギオパチーの可能性が高 い」という結論付けで終わってしまう可能性がある。「静 脈の視点で考光る」ことによって初めて「一元的に考え ると, BVRが関連した疾患があるのではないか」という 推察に到達することができる。

BVR との関連を疑うに至った「機能的静脈解剖」の側 面からのポイントは, 以下の 2 点である.

1）前交通静脈 (anterior communicating vein: AcomV) は左右の BVR を吻合している.

2 ) BVR は前頭葉下面からも側頭葉下面からも静脈 還流を受ける.

以上の 2 点を理解していれば, BVR に静脈圧上昇をき たす疾患が存在するとすれば，高い静脈圧が「対側の前 頭葉下面にも」,「同側の前頭葉のみならず側頭葉にも」 かかるため, 一元的に本疾患の病態を説明しうることに なる。

実際に血管撮影を行うと前頭蓋底部硬膜動静脈瘻が認 められ，その流出路は，嗅静脈から BVR ヘのルートが 唯一であった (Fig.4). 画像上, AcomVを介して, 対側 へ流出する所見は描出されていないが，腹腔内圧や胸胿 内圧が加われば容易に静脈圧が上昇するために（このこ と自体も静脈弁を有さない脳静脈そのものの特徵の一つ であるが), 多発性皮質下出血と本疾患とを関連付ける病 態説明としては十分であると考えられた。

BVR とその分枝の機能的かつ臨床的静脈解剖のポイ ントとしては, Fig. 5 のようなものを挙げることができ る.
BVR は 3 つの segment に分かれており ${ }^{3)}$, 各 segment 間での吻合形成不全が多く，その中で最も多いのが 1st segment と2nd segment の間での形成不全である。した がって, BVRに動静脈シャントが流出した際には, 形成 不全によって流出路が限定され, 病態が修飾される場合 がある.

1st segment では, 前出のように, 左右の BVR を吻合 するAcomVは, 静脈の側副血行路として最も重要と考 えられる。嗅静脈は, 血管解剖としては, 嗅溝の同定や 正中線と併せて直回の同定に用いられるが，臨床的には 本症例のように前頭蓋底部硬膜動静脈瘻において, 上矢 状洞への流出ルート以外の流出静脈として知っておかね ばならない．また，BVRは鉤静脈 (uncal vein) を介し て海綿静脈洞と吻合しており, BVR が 1st segment 2nd segment の間で形成不全の場合に発達しやすいこと が知られている2). 海綿静脈洞部硬膜動静脈瘻において, BVR へ流出したために深中大脳静脈 (deep middle cerebral vein；DMCV)へ逆流して脳出血をきたした症例 ${ }^{11} も$ 報告されており, 診断と治療の両面において重要と考え られる. DMCV は，4 本ある島静脈 (insular veins) が島 限で集合してできており, BVR と吻合している. 解剖的 指標としては, 前から 3 本目の島静脈である central insular vein は, 大脳中心溝の同定の指標として用いられてき $た^{12)}$.

2nd segment では, 後頭蓋窩静脈との交通路として脚 静脈 (peduncular vein) があり,下降して anterior pontomesencephalic vein に移行する. 左右の脚静脈を吻合する 後交通静脈 (posterior communicating vein; PcomV) は静 脈側副血行の観点から大切な役割を果たしている.また, 下脳室静脈（inferior ventricular vein）は血管に富む脈絡 叢乳頭腫の腫瘍の流出路となる場合がある. 


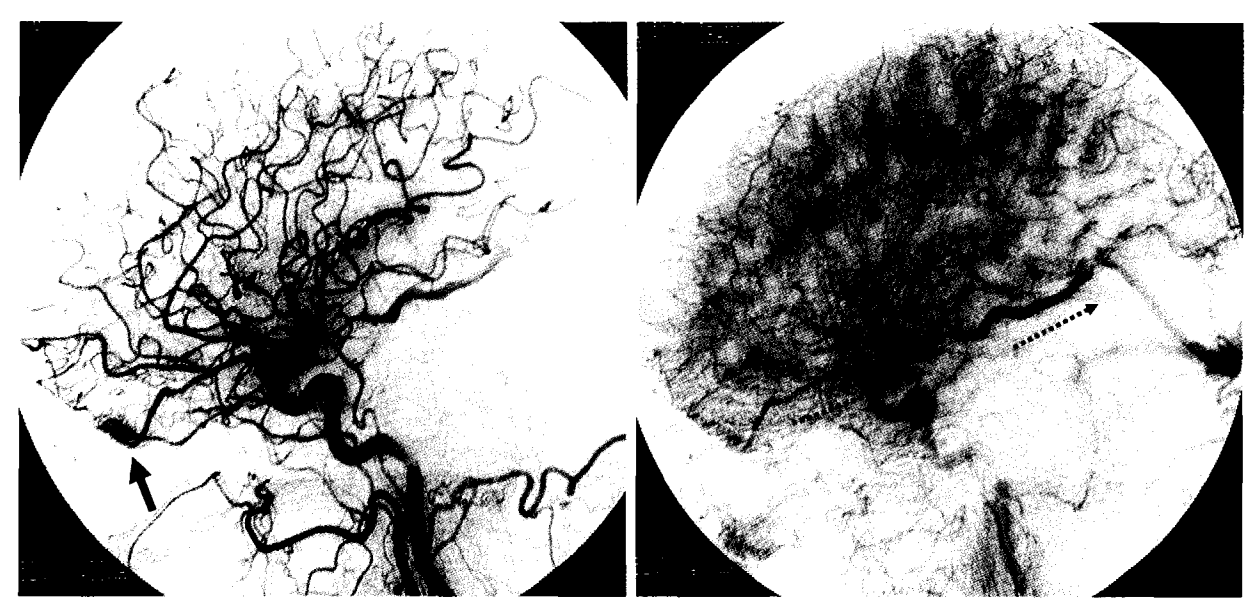

Fig. 4 Case 1: Arterial and capillary phase of left carotid injection (lateral views) of anterior cranial base dural arteriovenous fistula draining into the BVR via the olfactory vein.

3rd segment では, 側頭葉や後頭葉の下面からの静脈還 流を受ける以外に, 後頭蓋窩静脈との交通路として外側 中脳静脈（lateral mesencephalic vein）が重要である。 Yamamoto ${ }^{13)}$ は, 外側中脳静脈が $69 \%$ の例で BVR と SPS を吻合していると報告している.

MRI 以前の脳血管撮影による脳静脈解剖も決して無 視することはできないが，MRIが普及した現在において は, 機能的側面からポイントを押さえた静脈解剖の理解 が,「静脈の視点から考える」習慣を身に付けて臨床の場 に役立てるうえでは，より大切であると思われる。

\section{2] “venous cross road”を理解したうえでの ポイントを押さえた静眽読影}

脳血管病変の中で, 脳静脈の評価が必須である疾患の 代表的なものが硬膜動静脈瘦と脳動静脈奇形である. 特 にこれらの疾患において, 以下の点が読影のポイントと 考えられる。

1）病変がハイリスクであるか否かの評価：脳動静脈 奇形においては, 流出経路の評価, 流出路における狭窄 の有無, 手術時のランドマークとして利用可能な正常静 脈還流を有する静脈の確認などが大切である. また, 硬 膜動静脈瘦においては, retrograde leptomeningeal venous drainage (RLVD) の有無, varix や venous ectasia の有無, 脳静脈の側副血行路の発達程度とその経路の評 価, また正常静脈還流における venous congestion の有無 などが重要と思われる.

2 ）治療の strategy の決定：硬膜動静脈瘻に対する血 管内治療, 特に経静脈的塞栓術を行う場合には, いわゆ る “dangerous drainage”を残さないような治療法の計画 が必要である。また, アプローチ・ルートが唯一または

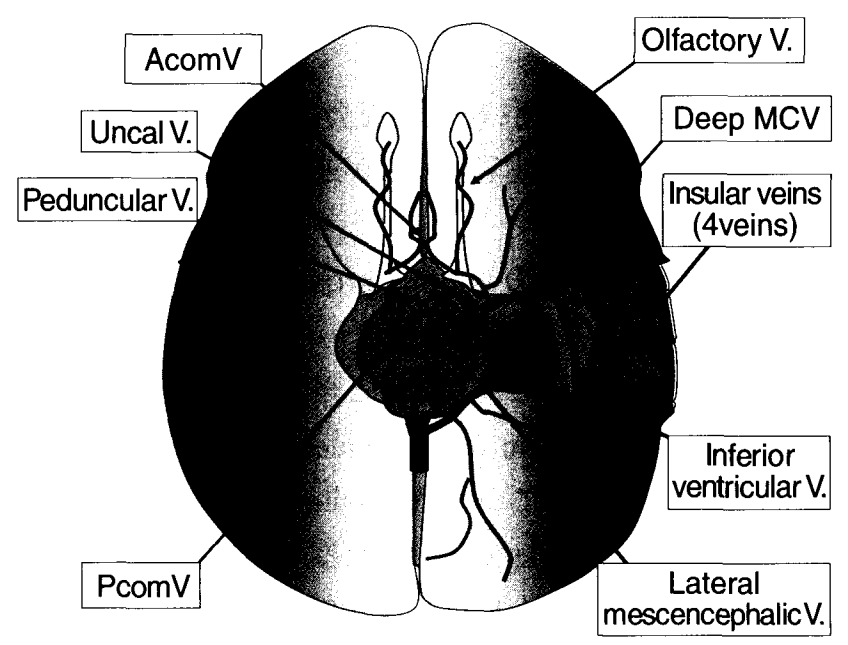

Fig. 5 Scheme of the basal vein of Rosenthal and its branches

$\mathrm{V}$; ; vein, MCV; middle cerebral vein.

主要な流出路である場合には, アプローチ・ルートにガ イディング・カテーテルやマイクロカテーテルが入った だけで流出障害を生じる場合があり, 思わぬ静脈圧上昇 を招いたり，新たな dangerous drainage が顕在化したり する場合があるため, 十分な注意が必要である.

これらの評価をするための静脈読影として重要なの が, venous cross roadの十分な理解である.

頭蓋底静脈の読影を行う場合に，それを中心に読影を 行うと便利なのが, (1)PVとその周辺の venous cross road, (2)頭蓋頸椎移行部の venous cross road の 2 つに分 けて考える見方である.もちろん, PV そのものも重要な venous cross road の一つであることはいうまでもない.

PVに関連してその周囲にある重要な venous cross road としては, 海綿静脈洞, ガレン静脈 (vein of Galen； 


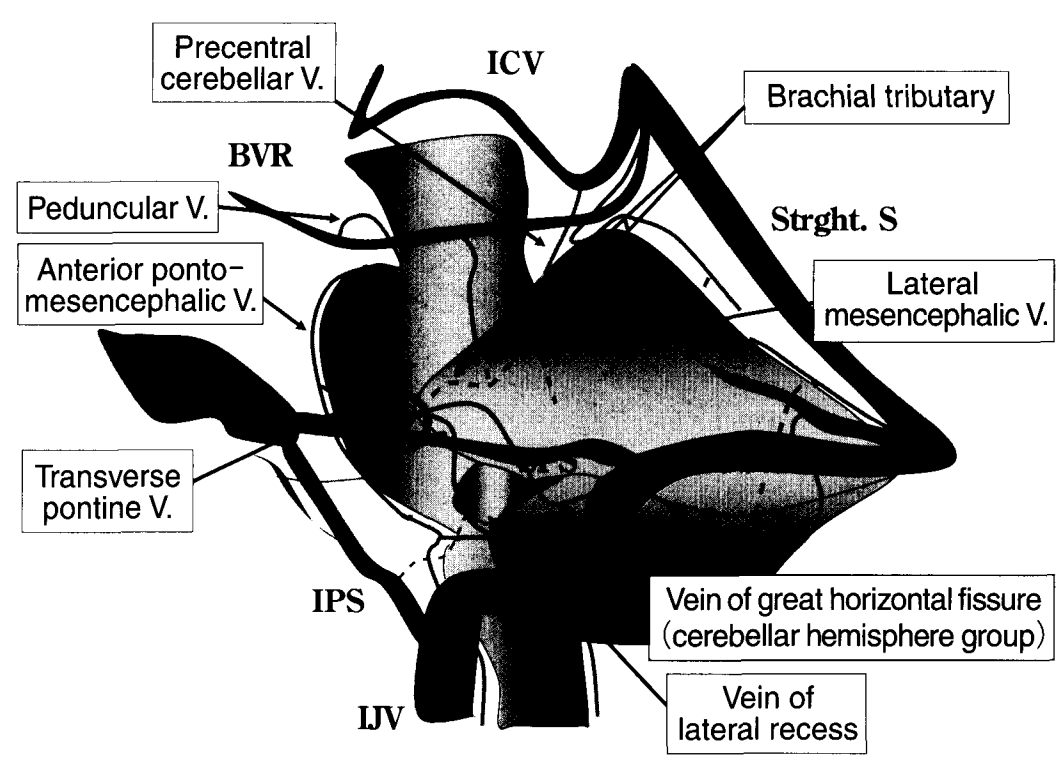

Fig. 6 Scheme of the posterior fossa veins and deep veins-lateral view-

$\mathrm{V}$. ; vein, ICV ; internal cerebral vein, BVR ; basal vein of Rosenthal, CS ; cavernous sinus, Strght S; straight sinus, Sgmd S; sigmoid sinus, SPS ; superior petrosal sinus, IPS ; inferior petrosal sinus, IJV; internal jugular vein.
VOG），テント静脈洞－静脈洞交会を挙げることができ る. 海綿静脈洞は, 他項で詳細が述べられているため, ここでは省略する。

\section{PV とその周囲の venous cross road}

前述の BVR と後頭蓋窩静脈との関係を側面からとら えた図を Fig. 6 に示した. BVR と後頭蓋窩静脈との主な 吻合は, peduncular vein $と$ lateral mesencephalic vein であ る。前者は, 下行して anterior ponto-mesencephalic vein に移行し, cranial angle で撮影した椎骨動脈撮影の静脈相 においては「逆ハート形」の左右の吻合部分からさらに 下行する特徵的な形態を示す. Anterior ponto-mesencephalic vein は，まれではあるものの脳底静脈叢 (basilar plexus）との間に bridging を形成する場合がある。この ため, 海綿静脈洞部硬膜動静脈瘻においては, 後頭蓋窩 静脈への流出という観点から，必ず着眼しなければなら ないポイントの一つということができる。実際に，脳幹 に症候性の venous congestion をきたした症例4)5) も報告 されている. Lateral mesencephalic vein も, cranial angle で撮影した椎骨動脈撮影の静脈相で，前述の「逆ハート 形」を示す左右それぞれの BVR の比較的 VOG 奇りから 下行してくるため，こ机も同定しやすい，さらに，VOG に流出するもう一つの重要な静脈が, 前中心小脳静脈 (precentral cerebellar vein； PcV) である.

$\mathrm{PV}$ と上記 3 本の静脈 (anterior ponto-mesencephalic vein, lateral mesencephalic vein, precentral cerebellar vein）とを吻合するのが “brachial tributaries”であり, PV に関連した病変の病態形成や流出路または迂回路と してもキーとなる静脈であるといえる，本静脈は variation が多く，左右のそれが高位で吻合したり低位で吻合
したりさまざまであり，また左右が吻合することなくそ れぞれの PcV に還流する場合もある8)。これによって, 対側まで病変の影響が及んだりする場合がある。また， PV は 1 本から数本までその本数においてもさまざまで あり, 後述のテント部硬膜動静脈摟などにおいては, 動 静脈シャントになっている PV と, 動静脈シャントに なっておらず正常脳静脈還流のみを受けている PV が混 在しているような場合もある.

Fig. 7 はテント部外側型硬膜動静脈㾞の症例である. マイクロカテーテルを用いて血管撮影を行うことによっ て, 詳細な血行動態と吻合を把握することができる．流 出路は, PV から brachial tributaries を介して lateral mesencephalic vein, precentral cerebellar vein の 2 本とさら に, 一部は brachial tributaries から対側まで流出して, テントの bridging vein に還流しているのが確認できる. したがって，このような症例に対して次に行うべきこと は, 正常静脈還流がこれらの経路を利用しているか否か の確認である，本症例に対しては，正常静脈還流を受け ていないことを椎骨動脈撮影で確認したうえで，開頭下 に流出路の遮断を計画した。動静脈瘻に関連して“red vein”を呈しているPV を遮断して根治しえた。

PVにはさらに重要な吻合路として, vein of lateral recess (of the fourth ventricle) へ流出するものと, vein of great horizontal fissure からテントの bridging vein へ流 出するルートがみられることがある．前者はJB 近傍， 特にIPS と吻合がみられることがある。後者は, 解剖学 的には lateral recess を走行していないことから, vein of the cerebellomedullary fissure と呼ぶべきであるとの意見 が少なくない7). 
Fig. 7 Case 2: Left middle meningeal arterial injection (lateral views) of tentorial dural arteriovenous fistula draining into the vein of Galen via the lateral mescencephalic vein and precentral cerebellar vein through brachial tributaries.

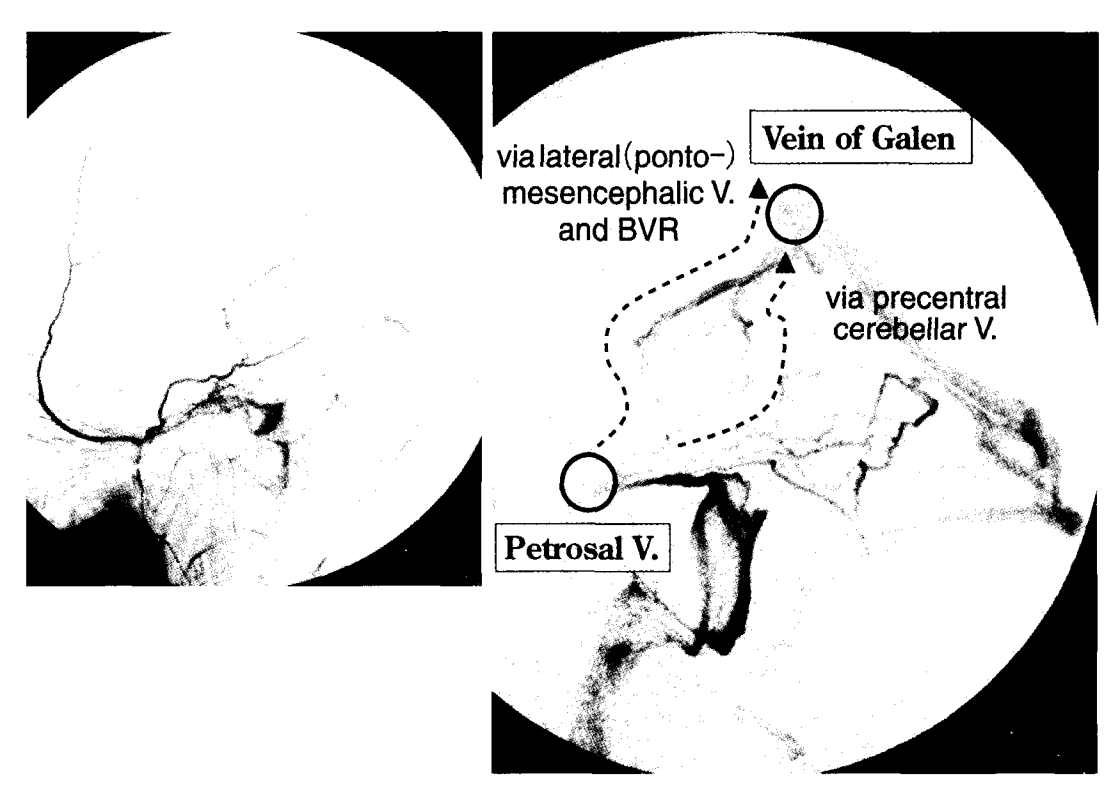

I thate

metion
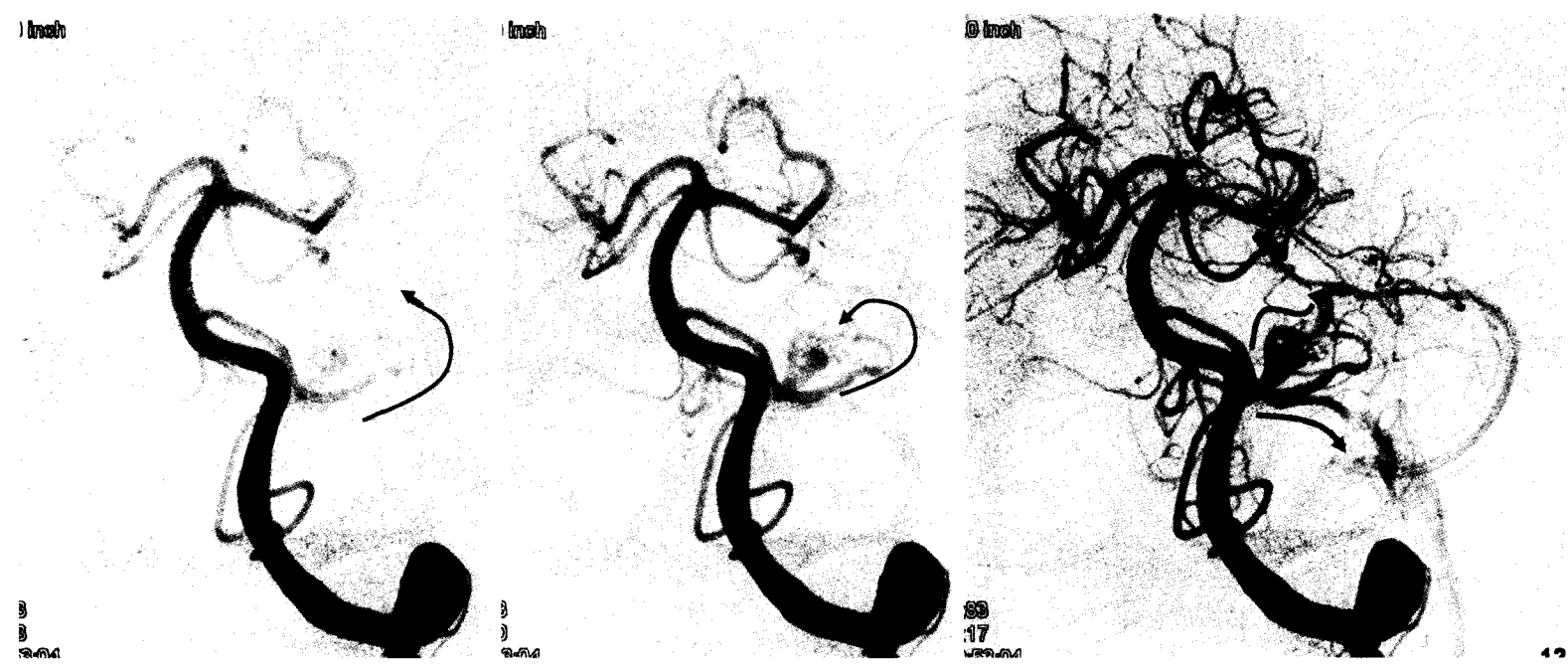

Fig. 8 Case 3: Left vertebral angiogram shows a cerebellopontine angle arteriovenous malformation draining into the superior petrosal sinus and a vein of lateral recess via petrosal vein.

Fig. 8 は小脳橋角部の脳動静脈奇形の症例である. 本 症例において流出路となっているのは, PVから SPS 流出する経路と, vein of lateral recess から JB 近傍に流出 するものがみられる。

\section{2. 頭蓋頸椎移行部の venous cross road}

頭蓋内にある静脈洞や静脈叢から，どのルートを介し て頭蓋骨を通過し，頭蓋外へ流出しているかは，いうま でもなく重要である. 頭蓋頸椎移行部にも重要な venous cross road が存在しているが，これらのうちには意見の 一致がみられていないものや名称の統一が行われていな いものも含まれている. 主だったものは, suboccipital cavernous sinus ${ }^{1 / 10)}$, anterior condylar confluent ${ }^{9)}$, petrosal confluens ${ }^{6) な と ゙ て ゙ あ る . ~}$

いずれにせよ,頭蓋頸椎移行部の読影を行ううえでは,
頭蓋内からどの経路を介して流出し，流出した血流はど の経路を通って, 最終的に頸部の 3 静脈 (内頸静脈, 外 頸静脈，椎骨静脈）のいずれに集約するかを読影せねば ならない．場合によっては，先に近位と遠位を同定し， それからその間の venous cross road は読影するほうが 近道の場合もある，特に，椎骨静脈系に関しては，まず (1)脊柱管内の内椎骨静脈叢, (2)脊柱管外の外椎骨静脈叢, に分けて読影を行うほうがわかりやすい，前者は脊柱管 との位置関係から同定しやすく, 後者は椎骨動脈の周囲 に存在する soboccipital cavernous sinus とそれよりも心 藏側の椎骨動脈の周囲の椎骨動脈静脈叢（vertebral artery venous plexus）に分けて考え, 動脈相の椎骨動脈 の走行と比較しながら同定を行うと，比較的容易に同定 できる，深頸静脈（deep cervical vein）は, 顆導出静脈 

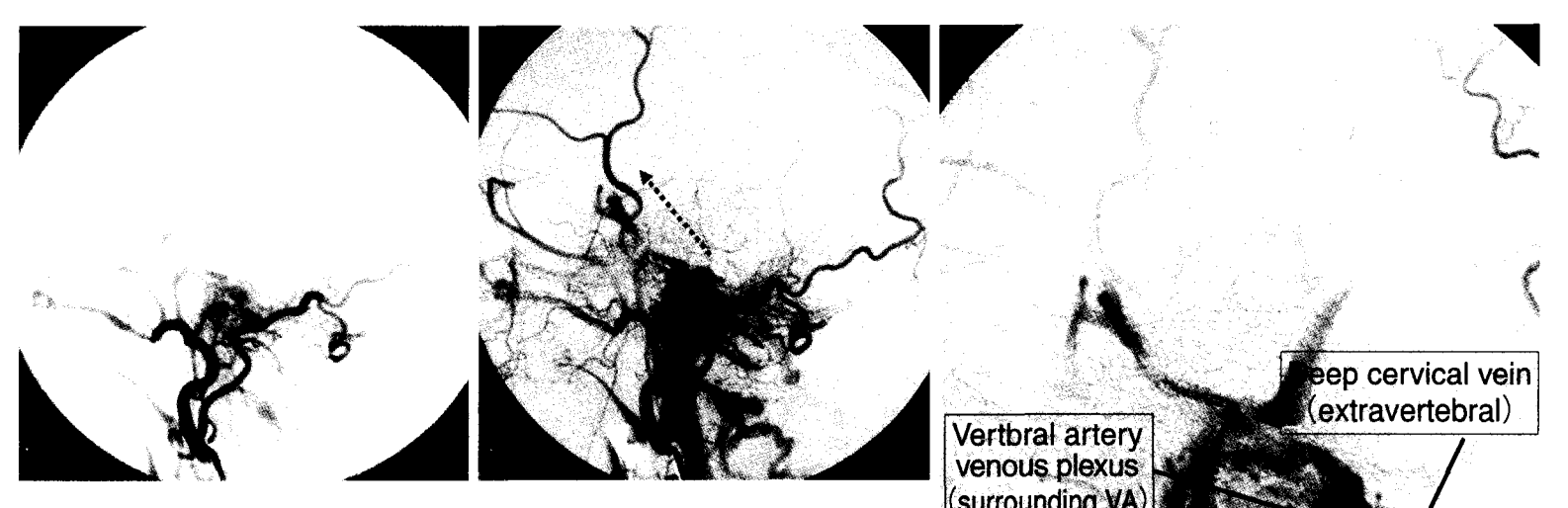

Fig. 9 Case 4: Left external carotid injection reveals a dural arteriovenous fistula draining into not only the vertebral venous system but also the inferior petrosal sinus and the sigmoid sinus.

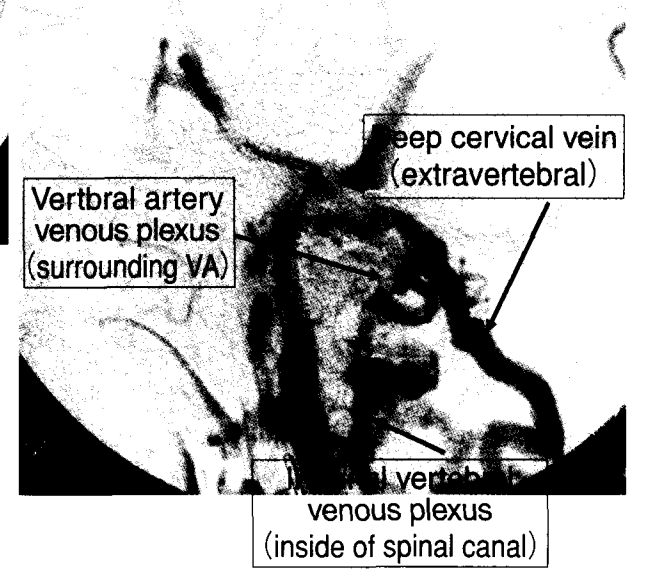

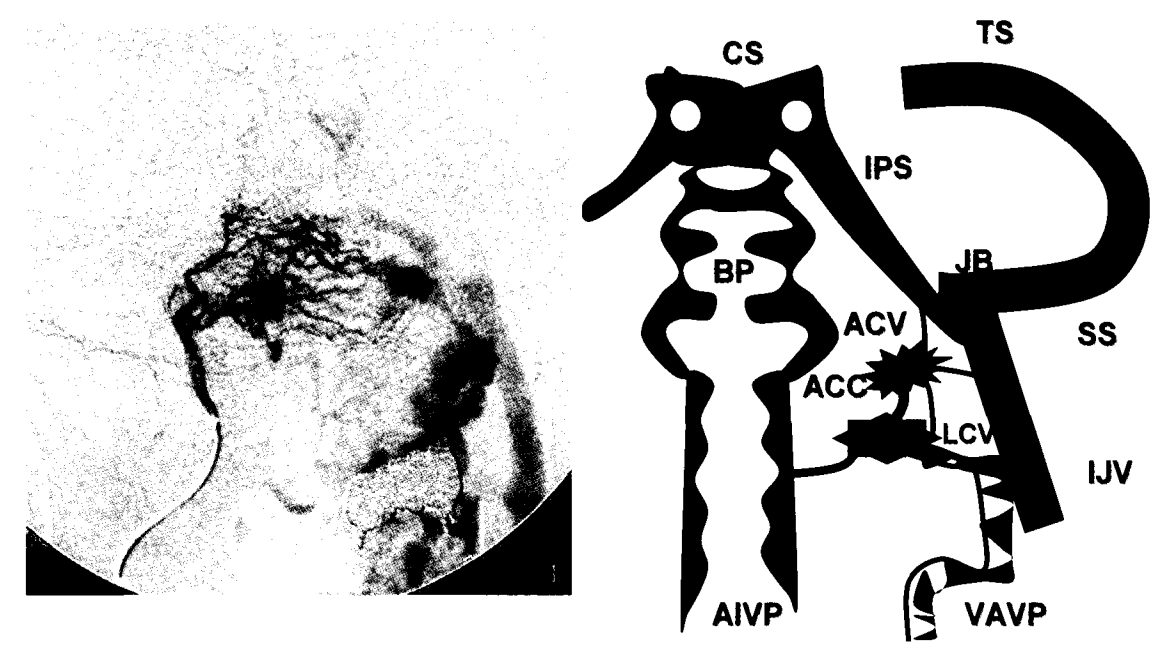

Fig. 10 Case 4:Right ascending pharyngeal artery injection (antero-posterior view) demonstrates a dural arteriovenous fistula involving the left anterior condylar confluent. (posterior condylar emissary vein) と連続しており, 通常 は仰臥位で血管撮影を行うため，比較的拡張してみえ， これも同定しやすい.いずれも最終的には椎骨静脈に集 約する。

Fig. 9 は, anterior condylar vein の硬膜動静脈瘻の症例 である。一見すると後方流出型の海綿静脈洞部硬膜動静 脈瘻に見誤りやすいが, 経時的に画像を追いかけて確認 すれば，そうでないことがはっきりする，確定診断のた めに有用なのが, 上行咽頭動脈の超選択的撮影である

(Fig. 10).

また, petroclival regionの腫瘍性病変に関しても, 以 下の点で重要と考えられる。

1 ) 開頭時に影響を及ぼす脳静脈の評価 (全体像)：特 に浅側頭静脈（superficial MCV）の還流パターン, emissary vein の流出パターンが重要と考えられる.
2 ）腫瘍近傍の静脈・静脈吻合路の評価: 3 次元静脈 構築による評価, 静脈側副血行の評価, 動画による venous congestion のチェック，総合読影を行うことなど が重要といえる。

頭蓋底腫瘍に関しては, 他項で多数取り上げられるた め,ここでは血管病変を中心に扱った。

\section{まとめ}

1）脳静脈に関してのより十分な情報を得るために は, 静脈相画像の描出を意識した工夫が必要である.

2 ）頭蓋底静脈の読影に際しては,「静脈の視点」を 持って病態を考え, それぞれポイントとなる venous cross road を十分に理解したうえでの評価が必要であ る. 


\section{文献}

1) Arnautović KI, al-Mefty $\mathrm{O}$, Pait TG, Krisht AF, Husain MM: The suboccipital cavernous sinus.J Neurosurg $\mathbf{8 6}$ : 252-262, 1997.

2）日向野修一，高橋明喜：臨床に必要な血管解剖。I，脳 血管一テント上一静脈系の解剖。静脈系の解剖。宮坂和 男編：脳脊髄血管造影マニュアル，東京，南江堂， 1997 , pp.99-119.

3) Huang YP, Wolf BS: The basal cerebral vein and its tributaries. in Newton TH, Potts DG (eds) : Radiology of the Skull and Brain, Vol. II Book3 Veins. St. Louis, CV Mosboy, 1974, pp.2111-2115.

4) Iwasaki M, Murakami K, Tomita T, Numagami Y, Nishijima $\mathrm{M}$ : Cavernous sinus dural arteriovenous fistula complicated by pontine venous congestion. A case report. Surg Neurol 65: 516-518, 2006.

5) Kai Y, Hamada JI, Morioka M, Yano S, Ushio Y: Brain stem venous congestion due to dural arteriovenous fistulas of the cavernous sinus. Acta Neurochir (Wien) 146: 1107-1111, 2004.

6) Katsuta T, Rhoton AL Jr, Matsushima T: The jugular foramen: Microsurgical anatomy and operative approaches. Neurosurgery $41: 149-201,1997$.

7) Matsushima T, Rhoton AL Jr, de Oliveria E, Peace D:
Microsurgical anatomy of the veins of the posterior fossa. $J$ Neurosurg 59, 63-105, 1983.

8）奥寺利男，宇都宮英鋼，小笠原哲三，前原史明：後頭蓋 窩正中構造を示現する三静脈一X 線解剖学的検討一. 藤 井清孝編 : 顕微鏡下手術のための脳神経外科解剖 II。東 京, サイメッドパブリケーションズ, 1990, pp.201-212.

9) San Millán Ruíz D, Gailloud P, Rüfenacht DA, Delavelle J, Henry F, Fasel JH: The craniocervical venous system in relation to cerebral venous drainage. AJNR Am J Neuroradiol 23: 1500-1508, 2002.

10) Takahashi S, Sakuma I, Omachi K, Otani T, Tomura N, Watarai J, Mizoi K: Craniocervical junction venous anatomy around the suboccipital cavernous sinus: Evaluation by MR imaging. Eur Radiol 15: 1694-1700, 2005.

11）高沢弘樹, 久保道也, 桑山直也, 長谷川真作, 堀江幸男, 平島 豊, 遠藤俊郎: 脳出血で発症した海綿静脈洞部硬 膜動静脈瘻の 1 例. No Shinkei Geka 33: 143-147, 2005.

12) Wolf BS, Huang YP: The insula and deep middle cerebral venous draining system: Normal anatomy and angiography. Am J Roentgenol Radium Ther Nucl Med 90: 472-489, 1963.

13) Yamamoto I, Kageyama $N$ : Microsurgical anatomy of the pineal region.J Neurosurg 53: 205-221, 1980.

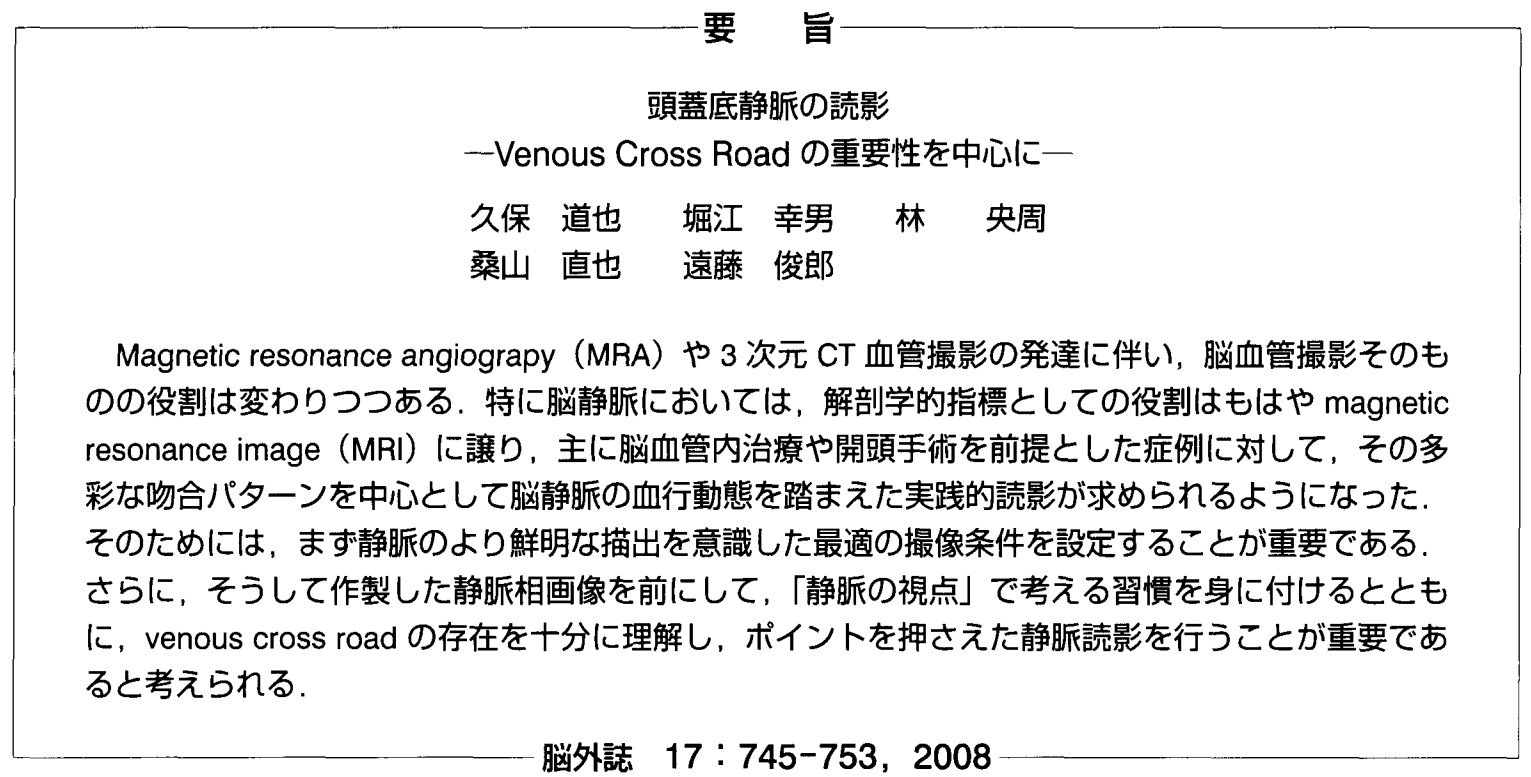

